\title{
PERENCANAAN KOMUNIKASI DALAM PENYULUHAN BAHAYA HIV/AIDS MELALUI PROGRAM KISARA
}

I Gusti Agung Laksmi Swaryputri

Program Studi Ilmu Komunikasi Fakultas Ilmu Komunikasi Universitas Dwijendra

Email : 1aksmiastawa@gmail.com

\begin{abstract}
Abstrak
AIDS adalah suatu penyakit yang belum ada obatnya dan belum ada vaksin yang bisa mencegah serangan virus HIV. Lembaga Swadaya Masyarakat yang konsen memberikan informasi tentang HIV/AIDS. Penelitian ini bertujuan untuk mengetahui Perencanaan Komunikasi dalam Penyuuhan Bahaya HIV/AIDS di Program KISARA Lembaga Swadaya Masyarakat Perkumpulan Keluarga Berencana Indonesia Denpasar. Metode penelitian yang digunakan yaitu deskriptif kualitatif. Dari hasil penelitian, dapat diketahuiPerencanaan Komunikasi dalam Penyuluahan Bahaya HIV/AIDS yang dilakukan Program KISARA Lembaga Swadaya Masyarakat Perkumpulan Keluarga Berencana Indonesia Denpasar Denpasar, meliputi 6 aspek Perencanaan. Diantaranya perencanaan sumber, pesan, khalayak, media, efek dan monitoring dan evaluasi. Dari semua aspek perencanaan tersebut sudah dilaksanakan dengan baik oleh Lembaga Swadaya Masyarakat Perkumpulan Keluarga Berencana Indonesia Denpasar program KISARA Denpasar.
\end{abstract}

Kata kunci: Perencanaan Komunikasi, Penyuluhan, Bahaya HIV/AIDS

\begin{abstract}
AIDS is a disease that has no cure and no vaccine that can prevent HIV virus attacks. Nongovernmental organizations concerned to provide information about HIV / AIDS. This study aims to determine the Penyuuhan Hazard Communication Planning HIV / AIDS Program Kisara Governmental Organization Indonesian Family Planning Association Denpasar. The method used is descriptive qualitative. From the research, it can be seen in Penyuluahan Hazard Communication Planning HIV / AIDS conducted Kisara Program Governmental Organization Indonesian Family Planning Association Denpasar, covering six aspects of planning. Among resource planning, message, audience, media, effects, and monitoring and evaluation. Of all the aspects of the plan have been implemented either by Non Governmental Organization Indonesian Family Planning Association Denpasar Kisara program.
\end{abstract}

Keywords: Communication Planning, Counseling, Danger HIV / AIDS

\section{PENDAHULUAN}

Penyakit HIV/AIDS merupakan suatu penyakit yang terus berkembang dan menjadi masalah global yang melanda dunia. Dalam hal ini, Program KISARA Lembaga Swadaya Masyarakat Perkumpulan Keluarga Berencana Indonesia mempunyai peran penting dalam Merencanakan Komunikasi Dalam Penyuluhan HIV/AIDS. Dalam merencanakan penyuluhan tersebut harus berdasarkan 6 aspek perencanaan yang meliputi : Diantaranya perencanaan sumber, pesan, khalayak, media, efek dan monitoring dan evaluasi. Sehingga dapat melakukan penyuluhan bahaya HIV/AIDS dengan baik. Berdasarkan latar belakang tersebut, dapat dirumuskan masalah penelitian ini yaitu bagaimanakah Perencanaan Komunikasi Dalam Penyuluhan Bahaya HIV/AIDS.Berdasarkan uraian rumusan masalah diatas, tujuan dari penelitian ini yaitu 
untuk mengetahui Perencanaan Komunikasi Dalam Penyuluhan Bahaya HIV/AIDS.Pengertian komunikasi menurut Raymond Ross adalah suatu proses yang menyortir, memiliki dan mengirim simbol-simbol yang sedemikian rupa sehingga dapat membantu pendengar dalam membangkitkan daya respon atau pemaknaan dari sebuah pemikiran yang selaras dengan yang dimaksud oleh komunikator.Suatu proses komunikasi tidak akan bisa berlangsung tanpa didukung oleh unsur - unsur yang saling berhubungan satu sama lain. Apabila salah satu unsur tersebut tidak ada, maka komunikasi tidak akan berjalan efektif (Cangara, 2015 : 31). Unsur - unsur komunikasi tersebut, antara lain:

a. Pengirim (source)

Pengirim disebut juga sebagai komunikator, adalah sumber informasi yang terdiri dari satu orang atau lebih, secara individu maupun kelompok.

b. Pesan (message)

Pesan merupakan sesuatu yang disampaikan pengirim kepada penerima, secara langsung maupun melalui media, berupa informasi, nasihat, hiburan, maupun propaganda.

c. Saluran atau Media (channel)

Media adalah alat untuk memindahkan pesan dari sumber ke penerima, seperti panca indera, surat, telepon, televisi, spanduk, maupun radio.

d. Penerima (receiver)

Penerima disebut juga sebagai komunikan, khalayak, atau sasaran dalam penyampaian pesan yang terdiri dari satu orang atau lebih.

e. Akibat atau Pengaruh (effect)

Pengaruh adalah akibat penerimaan pesan yang tampak pada perubahan pengetahuan, sikap dan tindakan seseorang.

f. Tanggapan Balik (feedback)

Tanggapan merupakan sebuah bentuk hasil pengaruh yang berasal dari penerima, ataupun pesan dan media, meskipun pesan belum sampai pada penerima.

\section{g. Lingkungan}

Lingkungan terdiri dari beberapa faktor yang dapat mempengaruhi jalannya komunikasi, seperti lingkungan fisik (geografis), lingkungan sosial (kesamaan bahasa, kepercayaan, adat istiadat), dimensi psikologis, dan dimensi waktu.

Menurut Harold D. Lasswell, komunikasi berfungsi agar manusia dapat mengontrol lingkungannya, beradaptasi dengan lingkungan tempat tinggal, dan melakukan transformasi warisan sosial pada generasi berikutnya. Fungsi generasi tersebut berdasarkan tipe komunikasi (Cangara, 2015 : 68), antara lain:

a. Komunikasi dengan Diri Sendiri 
Berfungsi untuk meningkatkan kematangan berpikir seseorang sebelum menarik sebuah keputusan.

b. Komunikasi Antar Pribadi

Berfungsi untuk meningkatkan hubungan, menghindari dan mengatasi konflik pribadi, serta berbagi pengetahuan dan pengalaman dengan orang lain.

c. Komunikasi Publik

Berfungsi untuk menumbuhkan semangat kebersamaan, mempengaruhi orang lain, dan memberi informasi mendidik serta menghibur.

d. Komunikasi Massa

Berfungsi untuk menyebarluaskan informasi, meratakan pendidikan, dan merangsang pertumbuhan ekonomi.

e. Dalam penelitian ini, tipe komunikasi yang terkait adalah Komunikasi Publik, yaitu proses komunikasi yang dapat menumbuhkan semangat didalam merencakan penyuluhan bahaya HIV/AIDS, dan dapat memeberikan informasi mendidik serta menghibur, sehingga membutuhkan perencanaan komunikasi agar proses penyuluhan berjalan dengan baik dan semaksimal mungkin.

Perencanaan komunikasi berasal dari kata perencanaan dan komunikasi. Perencanaan sendiri bersumber dari kata rencanayang berarti segala sesuatu yang akan atau harus dilakukan.Apabila segala sesuatu yang akan atau harus dilakukan itu diupayakan secara sistematis dan dinyatakan secara tertulis maka disebut perencanaan. Secara sederhana dapat dikatakan bahwa perencanaan pada dasarnya adalah suatu proses atau usaha atau tindakan membuat rencana. Tindakan-tindakan yang dilakukan dalam membuat suatu perencanaan tidak lain adalah tindakan pengambilan keputusan-keputusan mengenai apa yang akan dan harus dilakukan. G.R. Terry (Mardikanto, 1992:281) menyatakan bahwa perencanaan merupakan suatu proses pemilihan dan menghubunghubungkan fakta serta menggunakannya untuk menyusun asumsi-asumsi yang diduga bakal terjadi di masa mendatang untuk kemudian merumuskan kegiatan-kegiatan yang diusulkan untuk mencapai tujuan-tujuan yang diharapkan. Hal penting yang perlu dicatat adalah bahwa suatu perencanaan selalu berorientasi pada masa yang akan datang (future oriented). Sementara itu, komunikasi pada dasarnya adalah proses penyampaian pesan dari komunikator kepada komunikan, baik secara langsung maupun melalui media dengan tujuan untuk mengubah perilaku. Menurut Taksonomi Bloom (Winkel, 1990: 132), perubahan perilaku bisa terjadi dalam ranah kognitif (cognitive domain), ranah afektif (affective domain), maupun ranah psikomotor (psychomotor domain). Perilaku kognitif adalah perilaku yang berhubungan dengan aspek-aspek kognisi (kemampuan intelektual atau pengetahuan); perilaku afektif adalah perilaku yang berhubungan dengan sikap mental; dan perilaku psikomotorik adalah perilaku yang berhubungan dengan keterampilan (skill). Perubahan perilaku dalam aspek kognitif secara sederhana dapat diartikan sebagai perubahan dari keadaan tidak tahu menjadi tahu; perubahan perilaku 
afektif adalah perubahan dari tidak mau menjadi mau; dan perubahan perilaku psikomotorik adalah perubahan dari tidak mampu menjadi mampu.Hamad, Ibnu (2007 :

15) ada beberapa aspek-aspek yang mempengaruhi perencanaan komunikasi, yaitu :

1. Perencanaan Sumber/Komunikator : orang yang menyampaikan pesan

2. Perencanaan Pesan : informasi atau ide yang disampaikan

3. Perencanaan Media : sarana komunikasi

4. Perencanaan Khalayak/Komunikan : Audience pihak yang menerima pesan

5. Perencanaan Dampak/efek : efek apa yang akan dihasilkan

6. Perencanaan monitoring dan evaluasi (monev) Umpan Balik : Respon dari komunikan terhadap pesan yang diterimanya.

Udindan Abin (2006 : 5)merumuskan beberapa fungsi perencanaan, termasuk perencanaan komunikasi, yaitu:

1. Sebagai pedoman pelaksanaan dan pengadilan

2. Menghindari pemborosan sumber daya

3. Alat bagi pengembangan quality assurance

4. Upaya untuk memenuhi accountability

Perencanaan dipandang penting dan diperlukan bagi suatu organisasi antara lain dikarenakan :

1. Dengan adanya perencanaan diharapkan tumbuhnya suatu pengarahan kegiatan, adanya pedoman bagi pelaksanaan kegiatan-kegiatan yang ditujukan kepada pencapaian tujuan.

2. Dengan perencanaan, maka dapat dilakukan suatu perkiraan (forecasting) terhadap hal-hal dalam masa pelaksanaan kegiatan-kegiatan yang akan dilalui. Perkiraan dilakukan mengenai potensi-potensi dan prospek-prospek perkembangan tetapi juga mengenai hambatan-hambatan dan resiko-resiko yang mungkin dihadapi. Perencanaan mengusahakan supaya ketidakpastian dapat dibatasi sedini mungkin.

3. Perencanaan memberikan kesempatan untuk memilih sebagai alternative tentang cara yang terbaik (the best alternative) dan kesempatan untuk memilih kombinasi cara yang terbaik (the best combianation).

4. Dengan perencanaan dilakukan penyusunan sekala prioritas. Memilih urutanurutan dari segi pentingnya suatu tujuan, sasaran, maupun kegiatan usahanya.

5. Dengan adanya rencana, maka akan ada suau alat pengukur atau standar untuk mengadakan pengawasan dan evaluasi kinerja usaha atau organisasi. Udin dan Abin (2006 : 33)

Mengenai jenis perencanaan komunikasi, Udin dan Abin (2006 : 167-168) menguraikan beberapa jenis perencanaan, yaitu:

1. Perencanaan Adaptif 
Terjadi karena adanya tanggapan pada suatu pengembangan yang dilakukan secara eksternal. Dalam pengertian sempit, perencanaan itu berarti pemecahan masalah. Perencanaan itu dapat dengan mudah dipahami oleh semua pihak.

2. Perencanaan kontingensi

Perencanaan kontingensi merupakan pendekatan yang ditujukan untuk menciptakan kondisi yang pengaruhnya dapat dielakan dan diserap dengan biaya atau kerugian minimal.

3. Perencanaan kompulsif

Perencanaan kompulsif menentukan perincian mengenai apa yang seharusnya dan apa yang diharapkan dilakukan. Alat utamanya adalah reward (imbalan) bagi yang berhasildan punishment (hukuman) bagi yang tidak berhasil.

4. Perencanaan manipulatif

Perencanaan manipulatif mengandalkan berbagai jenis instrumen untuk mendapatkan suatu keuntungan. Alatnya adalah kesepakatan, pertukaran dan mempengaruhi orang lain.

5. Perencanaan indikatif

Perencanaan indikatif menyebarkan informasi yang dimaksudkan untuk meberi sinyal yang benar kepada individu dengan harapan agar pada gilirannya akan mengambil tindakan yang tepat.

6. Perencanaan bertahap (incremental)

Perencanaan bertahap adalah perencanaan yang megambil langkah pendek, mengoreksi kesalahan saat perencanaan itu dilaksanakan. 
7. Perencanaan otonomi

Merupakan perencanaan yang dilakukan sendiri dan bukan sebagai bagian dari perencanaannya.

8. Perencanaan pemulihan/perbaikan (ameliorative)

Perencanaan ini dirancang untuk memulihkan pada keadaan semula, tanpa pertimbangan mengenai apa yang akan terjadi. Tujuannya adalah kembali pada status quo.

9. Perencanaan normatif

Merupakan perencanaan jangka panjang, perencanaan untuk 25 sampai 40 tahun kedepan. Karekteristik utamanya adalah sifat yang umum, dan fungsinya adalah untuk membentuk pedoman dan rahan untuk perencanaan. Sifatnya menyeluruh sehingga fokusnya adalah pada perencanaan keseluruhan.

10. Perencanaan fungsional

Perencanaan fungsional memusatkan pada aspek tertentu dari seluruh masalah. Pada dasarnya jenis perencanaan itu sifatnya tersegmentasi tetapi tidak berfungsi sebagai pelengkap dari upaya perencanaan total. Dan perencanaan inilah yang berperan penting dalam perencanaan komunikasi dalam penyuluhan bahaya HIV/AIDS di program KISARA Lembaga Swadaya Masyarakat Perkumpulan Keluarga Berencana Indonesia.

Udin dan Abin (2006: 53-54) merumuskan 8 prinsip - primsip perencanaan komunikasi, yaitu:

1. Significance, yaitu tingkat kebermaknaan yang tergantung dari kepentingan sosial dari tujuan komunikasi yang diusulkan.

2. Feasibility, yaitu kelayakan teknis dan perkiraan biaya merupakan aspek yang harus dilihat secara realistik.

3. Relevance, yaitu konsep relevan mutlak perlu bagi implementasi rencana komunikasi.

4. Definitiveness, yaitu pengunaan teknik simulasi untuk menjalankan rencana dengan menggunakan data model buatan. Tujuannya adalah untuk meminimumkan kejadian yang tidak diharapkan yang akan mengalihkan sumber daya dari tujuan yang direncanakan.

5. Adaptability, yaitu perencanaan haruslah dinamis dan dapat berubah sesuai informasi sebagai umpan balik sistem.

6. Time, yaitu siklus alamiah pokok bahasa pada perencanaan, kebutuhan untuk merubah situasi yang tidak dapat dipikul.

7. Monitoring, yaitu menjamin rencana bekerja secara efektif.

8. Subject Matter, yaitu pokok-pokok bahasan yang akan direncanakan yang terdiri atas sasaran dan tujuan, program, sumber daya, anggaran, dan konteks social. 
Dahlan, M.D. (1985 : 30), pengertian tentang teknik penyuluhan harus dikuasai oleh setiap petugas penyuluhan dalam setiap kegiatannya, agar penyampaian materi penyuluhan dapat efektif dalam menjangkau sasaran khalayak. Didalam proses komunikasi, bahwa unsur "arus balik" merupakan aspek yanjg sangat penting untuk mengukur sejauh mana pesan komunikasi mendapatkan reaksi atau respon dari khalayak sasaran. Bila pesan komunikasi kita memperoleh tanggapan dari khalayak, maka dapat dikatakan bahwa apa yang kita samapaikan itu telah mencapai sasaran karena pesan yang diterimanya dapat dimengerti dan dipahami. Menurut Effendy (1986), bahwa sifak hakikat dari komunikasi adalah understanding atau memahami; sehingga tak mungkin seseorang melakukan kegiatan tertentu tanpa terlebih dahulu mengerti apa yang diterimanya.

Acquired Immunodeficiency Syndrome atau Acquired Immune Deficiency Syndrome (disingkat AIDS) adalah sekumpulan gejala dan infeksi (atau sindrome) yang timbul karena rusaknya system kekebalan tubuh manusia akibat infeksi virus HIV atau infeksi virus-virus lain yang mirip yang menyerang spesies lainnya (SIV, FIV dan lainlain).

Virusnya sendiri bernama Human Immunodeficiency Virus (atau disingkat HIV) yaitu virus yang memperlemah kekebalan pada tubuh manusia.Infeksi HIV disebabkan oleh human immunodeficiency virus, yang bekerja menghancurkan sel CD4 dalam tubuh. Sel CD4 adalah sel darah putih yang berperan penting dalam melawan infeksi dan penyakit yang mengancam tubuh. Virus ini menyebar melalui darah, air mani, atau cairan vagina.

Berikut adalah ciri-ciri orang terkena HIV yang terjadi 3-6 minggu pasca infeksi virus yang umum terjadi:

1. Demam

2. Nyeri tenggorokan dan batuk

3. Pembesaran kelenjar (di leher, selangkangan, ketiak atau bagian tubuh lainnya)

4. Nyeri kepala

5. Tulang dan otot yang nyeri dan pegal

6. Mudah lelah, letih dan lesu

7. Penurunan berat badan yang tidak terlalu besar

8. Menurunnya nafsu makan

9. Mual, muntah

10. Diare

11. Muncul ruam kemerahan pada kulit

12. Luka pada organ intim

13. Luka pada mulut (seperti sariawan) 
Satu-satunya cara untuk mencegah terinfeksi HIV adalah dengan menghindari kegiatan yang meningkatkan risiko tertular HIV. Pada dasarnya, mencegah selalu lebih baik dari pada mengobati. Berikut beberapa cara untuk mencegahnya yaitu:

1. Melalui Hubungan Seks

Risiko tertinggi infeksi HIV ditularkan melalui hubungan seks tanpa kondom melalui vagina maupun anal. Risiko tertular melalui seks oral rendah, tapi bukan berarti nol. Seks oral bisa menularkan penyakit Infeksi Menular Seksual lain seperti sifilis. Mainan dan alat bantu seks juga berisiko dalam menyebarkan HIV jika salah satu pengguna mainan dan alat bantu seks ini positif terinfeksi HIV. Cara terbaik untuk mencegah HIV dan penyakit infeksi menular seksual (IMS) lainnya adalah dengan memakai kondom untuk segala jenis penetrasi seks. Dan gunakan dental dam untuk melakukan seks oral. Dental dam adalah selembar kain berbahan lateks. Kain ini berfungsi sebagai penghalang antara mulut dan vagina atau anus. Hal ini bertujuan untuk menurunkan penyebaran IMS selama melakukan seks oral.

2. Pemakaian kondom

Jika tidak tahu status infeksi HIV pasangan, maka selalu gunakan kondom baru tiap melakukan hubungan seks anal maupun seks vaginal. Kondom tersedia dalam berbagai bentuk, warna, tekstur, bahan, dan rasa yang berbeda. Kondom tersedia baik untuk pria maupun wanita. Kondom adalah bentuk perlindungan paling efektif melawan HIV dan penyakit Infeksi Menular Seksual lainnya. Kondom bisa digunakan untuk hubungan seks apa pun. Sangat penting untuk memakai kondom sebelum kontak seksual apa pun yang muncul antara penis, vagina, mulut, atau anus. HIV bisa ditularkan sebelum terjadi ejakulasi. Ini terjadi ketika keluarnya cairan awal dari alat kelamin dan dari anus. Gunakan kondom yang berbahan lateks atau poliuretan (latex and polyurethane) ketika melakukan hubungan seks. Gunakan kondom jika pasangan mengalami ereksi, bukan sebelum ejakulasi.

3. Pemakaian pelumas

Pelumas digunakan untuk menambah kenyamanan dan keamanan hubungan seks dengan tujuan menambah kelembapan pada vagina maupun anus selama seks. Pelumas akan mengurangi risiko terjadinya kulit luka (sobek) pada vagina atau anus. Pelumas juga mencegah agar kondom tidak sobek. Hanya gunakan pelumas yang berbahan dasar air, bukan yang berbahan minyak. Pelumas yang berbahan minyak bisa melemahkan kekuatan kondom dan bahkan bisa merobek kondom.

4. Melalui Jarum dan Suntikan

Jika memakai jarum untuk menyuntikkan obat, pastikan jarumnya steril. Jangan berbagi jarum, suntikan, atau perlengkapan menyuntik lagi seperti spon dan kain. Berbagi jarum bisa meningkatkan risiko terinfeksi HIV dan virus lain yang ada 
di dalam darah, misalnya hepatitis C. Jika Anda ingin membuat tato atau tindik, pastikan selalu memakai jarum yang steril dan bersih. Jangan melakukan aktivitas ini di tempat sembarangan. Pastikan memeriksa soal jarum yang digunakan.

\section{METODE}

Menurut furchan A. (2004:72) adalah rencana dan struktur penyelidikan digunakan untuk memperoleh bukti bukti empiris dalam menjawab pertanyaan penelitian. Maka, rancangan yang digunakan dalam penelitian ini adalah Rancangan Deskriptif, dimana penelitian yang dilakukan memiliki tujuan utama memberikan gambaran atau deskripsi tentang suatu keadaan secara objektif, yaitu dengan menjabarkan bagaimana di program Kisara dapat merencanakan tahap - tahap dan berbagai proses untuk dapat mencapai tahap penyuluhan secara maksimal dan ada dampak positif terhadap kehidupan remaja dan masyarakat umum terkait bahaya HIV AIDS itu sendiri, Sehingga melalui rancangan deskriptif ini akan diperoleh data dan jawaban atas fokus permasalahan yang diteliti.

Subjek penelitian ini adalah informan dari jajaran staf di Lembaga Swadaya Masyarakat Perkumpulan Keluarga Berencana Indonesia KISARA Denpasar. Informan yang dimaksud terdiri dari 2 orang yakni:

1. Direktur Eksekutif Lembaga Swadaya Masyarakat Perkumpulan Keluarga Berencana Indonesia Denpasar yaitu bapak Ketut Sukanata S.H

2. Education and Community Develpoment yaitu Putu Noni Shintyadita.

Teknik pengumpulan data yang digunakan dalam penelitian ini ada 3 jenis, yaitu observasi, study dokumenter dan wawancara. Teknik observasi dilakukan dengan pengumpulan data dengan jalan pencatatan dan pengamatan secara sistematis dari fenomena-fenomena yang diselidiki. Data diperoleh langsung di tempat penelitian. study documenter Yaitu pengumpulan data data yang berasal dari dokumen-dokumen di program Kisara yang berhubungan dengan masalah yang diteliti. Sementara wawancara yaitu dengan mewawancarai dua orang informan, yaitu Education and community development program Kisara. Teknik wawancara adalah suatu cara melakukan tanya jawab kepada narasumber yang memungkinkan penulis memperoleh informasi tentang tahap-tahap perencanaan komunikasi apa saja yang dilakukan di program Kisara terhadap bahaya HIV AIDS dari tahap awal sampai terlaksananya Penyuluhan yang maksimal dan terlaksana dengan bai

Teknik analisis data yang dipakai dalam penelitian ini adalah teknik analisis data deskriptif kualitatif. Analisis data deskriptif kualitatif, yaitu suatu teknis analisis data dengan cara memaparkan secara lengkap apa yang penulis dapatkan selama melakukan riset di Lembaga Swadaya Masyarakat Perkumpulan Keluarga Berencana Indonesia dengan program Kisara bisa berupa kutipan wawancara dan program penyuluhan, 
sehingga didapatkan suatu kesimpulan yang rasional, yang kemudian hasilnya dilaporkan secara deskriptif.

Lokasi penelitian ini adalah di Lingkungan Gatot Subroto Tengah Kota Denpasar. Alasan dalam pemilihan lokasi ini adalah karena tempatnya strategis ada di pusat kota Denpasar, Lembaga Swadaya Masyarakat Perkumpulan Keluarga Berencana Indonesia adalah Lembaga Swadaya Masyarakat yang tertua di Bali yaitu berdirinya pada tangal 23 Desember 1957 dan mempunyai Program KISARA yang fokus terhadap Remaja dan dan dengan kegiatan Penyuluhan HIV/AIDS.

\section{HASIL dan PEMBAHASAN}

\section{Swadaya Masyarakat Perkumpulan Keluarga Berencana Indonesia Program KISARA Denpasa Bali}

Berdiri sejak 23 Desember 1957, Perkumpulan Keluarga Berencana Indonesia (PKBI) merupakan Lembaga Swadaya Masyarakat (LSM) yang memelopori gerakan Keluarga Berencana di Indonesia dan merupakan embrio dari organisasi gerakan keluarga berencana di Bali. Perkumpulan Keluarga Berencana Indonesia Daerah Bali mempunyai 9 cabang yang tersebar di 9 kab/kota di Bali sejak 1969. Saat ini melalui kerja sama multi pihak, Perkumpulan Keluarga Berencana Indonesia Daerah Bali telah dan sedang menjalankan beberapa program yang berkaitan dengan KB, Kesehatan Reproduksi, Penanggulangan HIV/AIDS dan pengembangan masyarakat. Perkumpulan Keluarga Berencana Indonesia (PKBI) merupakan Lembaga Swadaya Masyarakat (LSM) didalamnya mempunyai beberapa program kerja dan salah satunya adalah program Kita Sayang Remaja (KISARA). Perkumpulan Keluarga Berencana Indonesia (PKBI) merupakan Lembaga Swadaya Masyarakat (LSM) mempunyai struktur organisasi, yaitu : 
Struktur Program KISARA Lembaga Swadaya Masyarakat Perkumpulan Keluarga Berencana Indonesia Denpasar adalah sebagai berikut:

1. Koordinator KISARA

2. FAO (Finance Administrator dan Officer)

3. ECOMDEV (Education Community Development)

4. Divisi YCHC (Youth Clinic Health Care)

5. Divisi YOCA (Youth Campaign)

6. Divisi Desaign and Publishing

7. Divisi Research and Database

8. Divisi D4L (Dance For Live)

Kita Sayang Remaja (KISARA) yang diresmikan pada 14 Mei 1994 dengan anggota yang disebut relawan dan semuanya merupakan remaja. KISARA dibentuk karena kepedulian terhadap maraknya permasalahan kesehatan reproduksi remaja seperti hubungan seksual pra nikah, kehamilan remaja, penyakit menular seksual, HIV/AIDS termasuk juga penyalahgunaan narkotika. Didalam Program KISARA tersebut juga mempunyai program kerja yang salah satunya yaitu penyuluhan HIV/AIDS, struktur organisasi yang di miliki oleh Program KISARA, yaitu :

1. Koordinator KISARA mempunyai tugas:

Sebagai penanggung jawab program dan penanggung jawab project

2. FAO (Finance Administrator dan Officer)

a. Bertanggung jawab untuk mengurus keuangan

b. Untuk membuat segala berkas-berkas, seperti surat, MoU dll

c. Bertugas untuk membantu Koordinator disaat Koor berhalangan.

3. ECOMDEV (Education Community Development)

a. Merupakan divisi yang menaungi mengenai ceramah dan radio. Ceramah dapat berupa ceramah jemput bola atau ceramah undangan

b. Di bidang radio kisara bekerjasama dengan beberapa radio diantaranya RRI Pro 2 FM Denpasar, Cassanova, RPKD, Duta FM, dan beberapa radio lainnya.

4. Divisi YCHC (Youth Clinic Health Care)

Divisi ini berfokus pada layanan klinik (IMS, VCT dll) dan juga Konseling.

Konseling melalui 2 cara bisa melalui konseling tatap muka atau konseling via

Online melalu facebook@konseling kisara

5. Divisi YOCA (Youth Campaign)

Divisi ini menaungi mengenai aktivitas perayaan seperti HUT Kisara, Valentine Day, dan perayaan lainnya.

6. Divisi Desaign and Publishing 
Tugas divisi ini adalah membuat desaign spanduk, poster, leaflet dll. Divisi ini juga memiliki tugas untuk memaintenence Website dan semua sosial media yang dimiliki Kisara

7. Divisi Research and Database

Divisi ini bertugas untuk melakukan survey, penelitian dan monitoring evaluasi

8. Divisi D4L (Dance For Live)

Merupakan divisi Dance For Live sebuah tarian untuk ODHA. Divisi ini bertugas untuk melakukan inspire, educate, activate and celebrate.

Gambar Baliho Kegiatan Dance 4 Life Lembaga Program KISARA

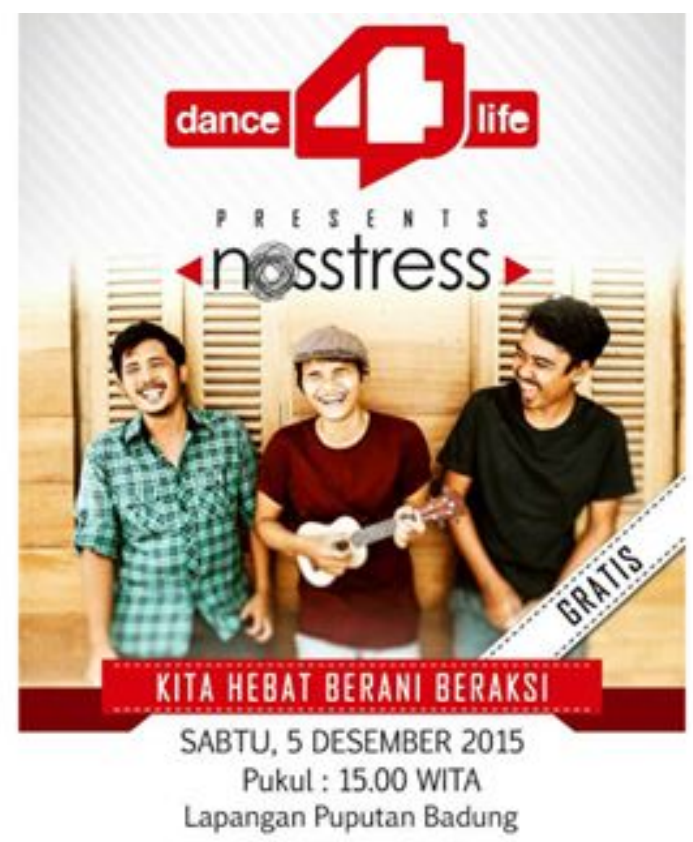

Dalam penyuluhan tersebut KISARA membutuhkan perencanan komunikasi yaitu upaya membuat rancangan pelaksanaan sebuat bentuk kegiatan komunikasi mulai dariperencanaan, pengorganisasian, pelaksanaan di lapangan, hingga monitoring dan evaluasi (monev) kegiatan komunikasi itu bersifat sistematis dan terukur. Sistematis disini berarti perencanaan komunikasi memiliki tahapan kerja yang terkait satu sama lain secara jelas dan konsisten. Sedangkan terukur artinya perencanaan komunikasi harus dapat dipantau (dimonitor) pelaksanaanya dan diukur hasil atau efeknya baik dikaitkan dengan tujuan penyuluhan itu sendiri dengan misi organisasi atau perusahaan.

Dalam menyusun perencanaan komunikasi kita berpedoman pada unsur-unsur komponen/ruang lingkup percanaan komunikasi itu sendiri yaitu :

1. Perencanaan sumber 
Perencanaan sumber atau komunikasi adalah seseorang atau sekelompok orang yang membuat perencanaan komunikasi mulai dari merencanakan komunikator, pesan, media, khalayak, efek, hingga monitoring dan evaluasi (monev).

2. Perencanaan pesan

Pesan dalam perencanaan komunikasi mencakup fungsi kedalam dan fungsi keluar. Kedua fungsi ini saling berkaitan dan tak dapat dipisahkan satu sama lain. Ke Dalam, pesan itu berfungsi untuk memberi nama, label, merk, idiologi dan seperangkat cirri khas atau karakteristik Perencanaan Komunikasi yang hendak kita suluh, keluar, pesan itu berfungsi untuk posisioning produk atau program di benak khalayak.

3. Perencanaan khalayak

Khalayak diidentikan dengan jumlah orang yang menerima pesan suatu kegiatan komunikasi dimana mereka dianggap anonim tersebar luas dan tidak saling mengenal, seperti para pembaca Koran pendengar radio dan penonton TV. Khalayak tidak dapat dipandang sebagai satu kesatuan social yang seragam. Kita tidak bisa melihatnya sebagai himpunan orang yang homogen. Khalayak itu terdiri dari individu-individu dengan jenis kelamin status social ekonomi orientasi dan minat yang berbeda-beda.

4. Perencanaan media

Supaya pesan sampai ke khalayak sasaran maka ia harus dikirimkan, dan lazimnya selalu menggunakan 1 atau lebih media yang menjangkau mereka. Agar pesan itu benar-benar sampai kepada menerimanya maka kita perlu memilih media yang dapat menjangkau khalayak sasaran tersebut. Dalam membuat perencanaan media para perencana komunikasi hendaknya mempertimbangkan2 hal yang saling berkaitan yaitu : siapa khalayak sasaran dan apa jenis media yang tepat untuk menjangkaunya.

5. Perencanaan dampak ( efek )

Efek adalah konsekuensi dari proses komunikasi dimana seseorang komunikator mengatakan sesuatu dalam suatu saluran pada orang/kalayak. Efek dari komunikasi merupakan rangkaian dari komponen komponen komunikasi lainnya, yaitu komunikator, pesan, saluran/media, dan penikmat/khalayak (McQuail dan Windahl, 1993: 13).Efek yang dihasilkan dari proses komunikasi meliputi 3 aspek, yaitu: kognitif, afektif, dan konatif

6. Perencanaan monitoring dan evaluasi (monev)

Dalam sebuah Perencanaan Komunikasi antara monitoring dan evaluasi sering dipersandingkan, monitoring dan evaluasi (monev) sesungguhnya merupakan 2 kegiatan yang berbeda. Monitoring adalah pemantauan atas proses pelaksanaan sebuah monitoring program sementara evaluasi adalah penilaian atas kinerja pelaksanaan dan hasil dari program yang telah dilaksanakan. Dalam kegiatan 
monitoring dan evaluasi (monev) merupakan kegiatan yang tidak terpisahkan dari kegiatan penyuluhan.

\section{PENUTUP}

\section{Simpulan}

Berdasarkan hasil penelitian yang telah dilakukan, dapat disimpulkan bahwa Perencanaan Komunikasi dalam Penyuluahan Bahaya HIV/AIDS yang dilakukan Lembaga Swadaya Masyarakat Perkumpulan Keluarga Berencana Indonesia Denpasar Program KISARA Denpasar meliputi 6 aspek Perencanaan, yaitu :

1 Perencanaan Sumber, memilih perencana sumber yang memiliki pengetahuan pengalaman keribilitas dan kompetensi di bidang penyuluhan bahaya HIV/AIDS.

2 Perencanaan Pesan, memakai branding/slogan "Jadilah Remaja yang Sehat dan Bertanggung Jawab, karena untuk Remaja HIV/AIDS dapat Dicegah dari Diri Sendiri"

3 Perencanaan Khalayak, terdiri dari remaja, orang orang yang berkebutuhan khusus, pelajar sekolah menengah pertama, sekolah menengah atas, perguruan tinggi dan orang-orang yang membutuhkan informasi mengenai bahaya HIV/AIDS.

4 Perencanaan Media, menggunakan Media elektronik, Power Point Spandukspanduk, dan baliho-baliho.

5 Perencanaan Efek, timbul efek kognitif, efek afektif, efek konatif.

6 Perencanaan Monitoring Evaluasi (Monev), dilakukan oleh Staff Divisi Research and Database Program KISARA Lembaga Swadaya Masyarakat Perkumpulan Keluarga Berencana Indonesia Denpasar Denpasar.

\section{Saran}

Program Kisara di Lembaga Swadaya Masyarakat PerkumpulanKeluarga Berencana Indonesia Denpasar sangat dibutuhkan untuk bisa terus memberikan informasi-informasi dan melakukan kegiatan-kegiatan positif seperti penyuluhan khususnya di wilayah denpasar maupun sekitarnya untuk bisa memberi wawasan lebih tentang bahaya virus HIV/AIDS. Perlu adanya feedback dari masyarakat untuk mengetahui apa kegiatan komunikasi yang dilakukan sudah tepat sasaran atau tidak. Disaat sosialisasi atau penyuluhan, Program KISARA di Lembaga Swadaya Masyarakat Perkumpulan Keluarga Berencana Indonesia Denpasar Denpasar sebaiknya memberi angket kepada khalayak penerima pesan untuk mengetahui tingkat ketertarikan khalayak akan kegiatan komunikasi yang dilakukan yang dapat di tinjau dari sumber, pesan, khalayak, media, dan efek. Dengan melakukan kegiatan monev berupa angket tersebut diharapkan Program KISARA Lembaga Swadaya Masyarakat Perkumpulan Keluarga Berencana Indonesia Denpasar Denpasar bisa mengevaluasi kekurangan masing masing dan untuk kedepannya kegiatan komunikasi yang dilakukan bisa semakin optimal. 


\section{DAFTAR PUSTAKA}

Adrial, H. 2014. Paradigma dan Model Penelitian Komunikasi. Bumi Aksara, Jakarta.

Cangara, Hadief.H. 2011. Pengantar Ilmu Komunikasi. Rajawali Pers, Jakarta.

Dahlan, M.D. 1985. Beberapa Pendekatan Dalam Penyuluhan (Konseling),Bandung Diponegoro.

Hamad, Ibnu. 2007. Perencanaan Program Komunikasi. Jakarta. UniversitasTerbuka.

Harun, Rochajat. 2008. Komunikasi Organisasi. Bandung. CV. Mandar Maju

- 2004. Ilmu Komunikasi: Teori dan Praktek. Bandung. RemajaRosdakarya.

Haryatmoko, 2007. Etika Komunikasi. Kanisius, Yogyakarta.

Josephson, Mattew. 1992. Communication. Armico Jaya, Yogyakarta.

Liliweri Alo. 2011. Komunikasi Organisasi. LKLS, Jakarta.

Mappiare. Andi. 1982. Psikolog Remaja. Usaha Nasional, Surabaya.

Moleong, Alex. 2001. Metode Penelitian Kualitatif. Bandung. Remaja Rosdakarya.

Muhammad Arni. 2005. Strategi Komunikasi. Bumi Aksara, Jakarta.

Mulyana, Deddy, dan Solatun. 2008. Metode Penelitian Komunikasi: Contoh-contoh Penelitian Kualitatif dengan Pendekatan Praktis. Bandung. Remaja Rosdakarya.

Onong, Effendi. 2003. Ilmu, Teori, dan Filsafat Komunikasi. Bandung : Citra Aditya Bakti.

Sudarma, Momon. 2014. Sosiologi Komunikasi. Mitra Wacana Media, Jakarta.

Sukardi Ketut. 2012. Prinsip-prinsip Komunikasi, Rineka Cipta, Jakarta.

Anonim, 2016, http://informasiana.com/pengertian-komunikasi-menurut-para-ahli/, diakses pada tanggal 10 Mei 2016. 